УДК 330.341 .424

\title{
ПРОБЛЕМЫ И ПЕРСПЕКТИВЫ ИННОВАЦИОННОГО РАЗВИТИЯ ПРОМЫШЛЕННОГО КОМПЛЕКСА ЕВРАЗИЙСКОГО ЭКОНОМИЧЕСКОГО СОЮЗА
}

\author{
В.Ф. БАЙНЕВ \\ д-р экон. наук, проф., зав. кафедрой инновационного менеджмента \\ Белорусского государственного университета, г. Минск \\ В.Т. ВИННИК \\ гл. советник Республиканской ассоциации предприятий промышленности «БелАПП», г. Минск
}

\begin{abstract}
Аннотация
В статье анализируются общемировые тенденции развития промышленного комплекса в технологически развитых странах. Показано, что основу его глобальной конкурентоспособности составляет активная промышленная политика новой индустриализации, ориентированная на формирование VI-го технологического уклада и вертикальную интеграцию активов. С учетом этого предложены принципы формирования межгосударственной промышленной политики, обеспечивающей конкурентоспособность стран Евразийского экономического союза.
\end{abstract}

Abstract

The article is devoted to the analysis of the global trends of the industrial complex in the technologically advanced countries. It is shown that the basis of global competitiveness of upmentioned countries is the active policy of the new industrialization, focused on the formation of the VI-th technological order and vertical assets integration. Based on these provisions we propose new principles of inter-state industrial policies that ensure the competitiveness of the Eurasian Economic Union.

\section{ВВЕДЕНИЕ}

Наша цивилизация вошла в технотронную эпоху третьего тысячелетия. Очевидно, что уже в нынешнем веке место той или иной страны в мировой табели о рангах будет всецело определяться состоянием ее промышленного комплекса, индустрии. Это однозначно следует из того, что промышленность - это именно та отрасль, где, с одной стороны, максимальна концентрация высокотехнологичных производств, составляющих «становой хребет» инновационной, основанной на интеллекте и знаниях, наукоемкой экономики. С другой стороны, индустриально-промышленный комплекс является производителем прогрессивных средств труда для прочих отраслей и сфер жизнедеятельности современного человека, а значит, именно он является подлинным «катализатором» инноваций и «локомотивом» инновационного развития страны в целом. Поэтому в складывающихся условиях неизмеримо возрастает роль промышленной политики, позволяющей обеспечить инновационное развитие этой стратегически значимой отрасли, а значит, и национальной экономики в целом.

Главная цель инновационной политики в индустриально-промышленном комплексе на современном этапе ускоренное формирование VI-го технологического уклада, реализация последовательного приращения выпуска наукоемкой и высокотехнологичной продукции с высокой долей добавленной стоимости на основе программноцелевого (планового) регулирования процессов организационной, структурной и технологической модернизации индустриального воспроизводства. Не секрет, что лидеры мировой экономики, в основном, уже завершили формирование V-го технологического уклада, базовыми компонентами которого являются компьютеры, малотоннажная химия, телекоммуникации, электроника, сетевые технологии. Сегодня становятся актуальными факторы, относящиеся к VI укладу, включая биотехнологии, проектирование живого, вложения в человека, новое природопользование, нанотехнологии, робототехнику, новую медицину, высокие гуманитарные технологии, проектирование будущего и управление им, конструирование социальных субъектов. Очевидно, что в XXI веке сохранить свой экономический суверенитет смогут лишь те страны, которые в ближайшие годы завершат формирование $\mathrm{V}$-го технологического уклада и перейдут к активному освоению новейших технологий. Остальным же на первых порах будет уготована роль «дровосеков и водоносов», а затем они, вероятнее всего, вообще исчезнут с политической карты мира.

Именно поэтому, как это утверждает российский академик С.Ю. Глазьев, в становление нового, VI-го по счету, технологического уклада, ядром которого являются нано-, био-, информационные, коммуникационные и другие высокие, базирующиеся на достижениях промышленности технологии, лидеры мировой экономики вложили до $80 \%$ всех своих антикризисных денег, что эквивалентно сумме в триллионы долларов. В результате данный комплекс высокотехнологичных промышленных отраслей растет темпом $35 \%$ в год, а к концу десятилетия он выйдет на долговременное устойчивое развитие с годовым темпом $20-25 \%$ и объемом инвестиций до 400 млрд долларов. Получается, модернизация и достижение глобальной конкурентоспособности немыслимы без кардинального технико-технологического прорыва в промышленно-индустриальном комплексе.

Несмотря на то, что лидеры мировой экономики, заинтересованные в наращивании своего отрыва от остального мира, искусно маскируют истинное содержание грядущей эпохи мудреными названиями типа «постиндустриальное общество», «сервисная экономика услуг», «информационное общество» и т.п., специалисты настойчиво поправляют: мир вступает не в постиндустриальную, а в неоиндустриальную эпоху $[1,2,3]$. И это упорство постепенно начинает давать плоды. В последние годы о необходимости нового индустриального рывка стали задумываться не только 
ученые и специалисты-практики, но и на верхних этажах властной вертикали постсоветских стран [4]. Ученые опятьтаки настойчиво подсказывают, что решение данной задачи немыслимо без массированного производства и внедрения в хозяйственную жизнь прогрессивных средств и предметов труда, то есть без мощного промышленноиндустриального рывка в рамках новой индустриальной политики, без неоиндустриализации.

К счастью, сегодня концептуальные и теоретические основы новой индустриальной политики, нацеливающей на скачкообразное повышение производительности труда, достаточно хорошо разработаны. В ее фундаменте лежит открытый в 1996 г. российским ученым С.С. Губановым экономический закон вертикальной интеграции, запрещающий извлечение прибыли с отдельных, промежуточных стадий единых цепочек создания стоимости. Иными словами, согласно этому экономическому закону, любая цепочка взаимосвязанных производств, последовательно осуществляющих передел сырья в конечную продукцию, функционирует с максимальной экономической эффективностью только в том случае, если прибыль снимается со всей цепочки в целом, а не с каждого из ее звеньев $[1,5]$.

Данный закон, во-первых, исчерпывающе объясняет причины ускоренного формирования и роста монопольной силы транснациональных корпораций (ТНК), интегрирующих под своим контролем все фазы передела сырья в конечную продукцию, начиная со стадии НИОКР и заканчивая организованным сбытом и утилизацией произведенной продукции. Во-вторых, усиление экономической роли ТНК, для которых страны и континенты - это всего лишь территории базирования их структурных подразделений, в свою очередь, предопределяет воочию наблюдаемые ныне процессы активной межгосударственной интеграции (например, в рамках того же ЕС или формирующегося Евразийского экономического союза). И наконец, в-третьих, данный закон исчерпывающе объясняет то, почему осуществленная вопреки его требованиям приватизация, которая под лозунгом перехода к «чудотворной» рыночной экономике безжалостно расчленила некогда целостный народнохозяйственный комплекс СССР, разрезав единые цепочки создания добавленной стоимости на конкурирующие звенья, привела к снижению эффективности, деиндустриализации и сырьевой примитивизации национальных экономик постсоветских стран.

Следует пояснить, что проблемам инновационного развития промышленного комплекса Беларуси и союзных стран в последнее десятилетие уделяется значительное внимание в работах как зарубежных [1-7], так и отечественных специалистов [8-10], включая авторов данной статьи [11-15]. Особенность нынешнего этапа развития промышленного комплекса постсоветских стран, желающих остаться в когорте технологически развитых держав, состоит в том, что Армения, Беларусь, Казахстан, Кыргызстан и Россия приступили к практическому формированию скоординированной, согласованной межгосударственной промышленной политики в рамках Евразийского экономического союза (ЕАЭС). В настоящее время активно разрабатываются концептуальные и теоретические основы, принципы, механизмы и инструменты реализации такой политики, инициирована соответствующая нормотворческая деятельность. В связи с этим видится, что на сегодняшний день исключительно важной задачей является то, чтобы прогрессивные наработки отечественных и зарубежных ученых все-таки были учтены в нормативных правовых актах, призванных регулировать экономические взаимоотношения союзных стран, а не были игнорированы чиновниками, как это, увы, очень часто бывает в практике постсоветских стран.

\section{РЕЗУЛЬТАТЫ И ИХ ОБСУЖДЕНИЕ}

Вопреки тому, что в нынешнем мире всецело господствуют те страны и народы, кто продуцируют лучшие автомобили, самолеты, локомотивы, суда, электронику, бытовую технику, вооружения и т.П., а также средства их производства, республики бывшего СССР в последние десятилетия демонстрируют беспрецедентное снижение их промышленного потенциала. Как в отечественной, так и зарубежной печати мы неоднократно писали о деиндустриализации стран бывшего СССР, таящей прямую угрозу их экономическому и политическому суверенитету (см., например, [1215]). Здесь же ограничимся лишь показательной информацией о падении промышленного производства России - самой мощной страны региона (табл. 1).

Столь внушительное снижение промышленного потенциала России и других стран региона во многом произошло из-за того, что в последние десятилетия существенно изменился характер конкуренции, которая, по мнению многих ученых, сегодня явно угасает, уступая место кооперации и сотрудничеству [17]. Поэтому наши либеральнорыночные реформы, ориентированные на классическую конкурентно-рыночную доктрину развития, вопреки заверениям их идеологов привели, увы, не к инновационному прорыву республик бывшего СССР, который и без того занимал одно из лидирующих мест в области научно-технического прогресса (НТП), а наоборот, выступили причиной разгрома его научного, промышленного, экономического потенциала. На фоне наших наивных упований на «чудотворную» силу свободных рынков, «здоровой конкуренции» отечественных предприятий друг с другом, малого и среднего бизнеса технологически развитые страны, наоборот, демонстрируют быстрый рост монопольной силы своих крупных ТНК (табл. 2).

Благодаря быстро растущим ТНК, конкуренция выросла из национальных границ и вышла на межгосударственный, глобальный уровень, где нынче за ограниченные ресурсы на равных сражаются не просто крупные вертикально интегрированные корпорации, но целые страны и даже их блоки (например, тот же ЕС). Очевидно, что в сложившихся условиях неизмеримо возрастает экономическая роль государства. Неслучайно, согласно статистике МВФ, за последние полтора века доля государственных расходов в ВВП 30 наиболее развитых стран мира, ныне входящих в ОЭСР, выросла в среднем в 4,5 раза (табл. 3). 
Таблица 1 - Динамика производства важнейших видов промышленной продукции в России в период либерально-рыночных реформ 1990-2013 гг. [16]

\begin{tabular}{|c|c|c|c|}
\hline Продукция & 1990 г. & 2013 г. & $\begin{array}{l}2013 \text { г. в \% } \\
\text { к } 1990 \text { г. }\end{array}$ \\
\hline \multicolumn{4}{|c|}{ Технически сложная промышленная продукция } \\
\hline Турбины всех видов, млн кВт & 12,5 & 3,1 & 24,8 \\
\hline Электродвигатели переменного тока, тыс. шт. & 2000 & 629 & 31,4 \\
\hline Краны мостовые электрические, шт. & 2943 & 2411 & 81,9 \\
\hline Экскаваторы, шт. & 23100 & 1753 & 7,6 \\
\hline Тракторы, тыс. шт. & 214 & 8,6 & 4,0 \\
\hline Зерноуборочные комбайны, тыс. шт. & 65,7 & 5,4 & 8,2 \\
\hline Металлорежущие станки, тыс. шт. & 74,2 & 3,4 & 4,6 \\
\hline Машины стиральные, млн шт. & 5,4 & 3,8 & 70,9 \\
\hline Троллейбусы, шт. & 2308 & 517 & 22,4 \\
\hline Грузовые автомобили, тыс. шт. & 720 & 389 & 54,0 \\
\hline Мотоциклы, тыс. шт. & 765 & 27 & 3,5 \\
\hline Вагоны пассажирские магистральные, шт. & 2532 & 782 & 30,9 \\
\hline Самолеты гражданские, шт. & 86 & 31 & 36,0 \\
\hline $\begin{array}{l}\text { Вычислительная техника, ее части и принадлежности, } \\
\text { млрд руб. }\end{array}$ & $264^{*}$ & 39,8 & 15,1 \\
\hline \multicolumn{4}{|c|}{ Энергетические и материальные производственные ресурсы } \\
\hline Электроэнергия, млрд кВт·ч & 1082 & 1051 & 97,1 \\
\hline Сталь, млн т & 90,4 & 68,8 & 76,1 \\
\hline Готовый прокат черных металлов, млн т & 64,0 & 57,9 & 90,4 \\
\hline $\begin{array}{l}\text { Конструкции и изделия сборные железобетонные, } \\
\text { млн куб. м }\end{array}$ & 79,4 & 26,9 & 33,8 \\
\hline Цемент, млн т & 83,9 & 66,4 & 79,1 \\
\hline Кирпич строительный, млрд усл. кирпичей & 24,5 & 11,2 & 45,7 \\
\hline Пиломатериалы, млн куб. м & 75,0 & 21,0 & 28,0 \\
\hline Древесноволокнистые плиты твердые, млн усл. кв. м & 483 & 419 & 86,7 \\
\hline Бумага, млн т & 5,2 & 4,7 & 90,4 \\
\hline Картон, млн т & 3,1 & 3,0 & 96,8 \\
\hline Синтетические каучуки, тыс. т & 2100 & 1483 & 70,6 \\
\hline Синтетические и искусственные волокна, тыс. т & 613 & 146 & 23,8 \\
\hline Серная кислота, млн т & 12,8 & 10,3 & 80,5 \\
\hline Сода кальцинированная, млн т & 3,2 & 2,4 & 76,6 \\
\hline \multicolumn{4}{|c|}{ Важнейшие продовольственные товары } \\
\hline Мясо, включая субпродукты I категории, млн т & 6,6 & 6,1 & 92,4 \\
\hline $\begin{array}{l}\text { Цельномолочная продукция } \\
\text { (в пересчете на молоко), млн т }\end{array}$ & 20,8 & 8,6 & 41,3 \\
\hline Масло животное, тыс. т & 833 & 222 & 26,7 \\
\hline Caxap & 6,2 & 4,9 & 79,0 \\
\hline \multicolumn{4}{|c|}{ Важнейшие непродовольственные товары народного потребления } \\
\hline Ткани хлопчатобумажные, млрд кв. м & 5,62 & 1,3 & 23,1 \\
\hline Ткани шерстяные, млн кв. м & 466 & 12,8 & 2,7 \\
\hline Ковры и ковровые изделия, млн кв. м & 43,5 & 22,3 & 51,3 \\
\hline Чулочно-носочные изделия, млн пар & 872 & 249 & 28,6 \\
\hline Трикотажные изделия, млн штук & 770 & 144 & 18,7 \\
\hline Пальто, полупальто, млн шт. & 3,4 & 1,27 & 37,3 \\
\hline Обувь, млн пар & 385 & 114,0 & 29,0 \\
\hline
\end{tabular}

Разумеется, описанные глобальные тенденции не могли не отразиться на развитии индустриальнопромышленного комплекса лидирующих стран, которые были вынуждены прибегнуть к активному использованию рычагов и инструментов в рамках национальной научно-технической, инновационной, промышленной политики. По мнению многочисленных экспертов, все «экономические чудеса» XX века (Япония, Германия, Южная Корея, Китай, Индия) являются следствием соответствующей глубоко продуманной и высокоэффективной государственной инновационной промышленной политики, всемерно способствующей вертикальной интеграции взаимосвязанных производств, прежде всего, в рамках ТНК. При этом государственная поддержка НТП и промышленности в странах, совершивших научно-технологический прорыв, не только не ослабевает, но и нарастает быстрыми темпами [6, с. 26-27].

Долгосрочная тенденция нарастания концентрации капитала и прибыли под контролем крупных корпораций США в 1970-2005 гг. [5, с. 20] 


\begin{tabular}{|c|c|c|c|c|c|c|c|c|}
\hline \multirow{2}{*}{ Год } & \multirow{2}{*}{ Всего, \% } & \multicolumn{7}{|c|}{ Размер компании (величина ее капитала), млн долл. } \\
\cline { 2 - 9 } & менее 10 & $\begin{array}{c}\text { от 10 } \\
\text { до 25 }\end{array}$ & $\begin{array}{c}\text { от 25 } \\
\text { до 50 }\end{array}$ & $\begin{array}{c}\text { от 50 } \\
\text { до 100 }\end{array}$ & $\begin{array}{c}\text { от 100 до } \\
250\end{array}$ & $\begin{array}{c}\text { от 250 до } \\
1000\end{array}$ & $\begin{array}{c}1000 \text { и } \\
\text { выше }\end{array}$ \\
\hline \multicolumn{8}{|c|}{ Доля в совокупном капитале, \% } \\
\hline 1970 & 100 & 11,95 & 3,54 & 3,48 & 4,49 & 8,26 & 19,45 & 48,82 \\
\hline 1990 & 100 & 5,42 & 2,83 & 2,13 & 2,76 & 4,71 & 10,93 & 71,21 \\
\hline 2000 & 100 & 3,54 & 1,76 & 1,49 & 1,87 & 3,09 & 8,03 & 80,23 \\
\hline 2005 & 100 & 2,90 & 1,47 & 1,20 & 1,54 & 2,44 & 7,24 & 83,21 \\
\hline \multicolumn{8}{|c|}{ Доля в совокупной прибыли, \% } \\
\hline 1970 & 100 & 9,84 & 2,84 & 2,93 & 3,85 & 8,10 & 20,52 & 51,91 \\
\hline 1990 & 100 & 7,74 & 4,69 & 2,51 & 2,42 & 3,20 & 6,46 & 72,99 \\
\hline 2000 & 100 & 6,02 & 2,48 & 1,24 & 1,00 & 1,27 & 5,49 & 82,50 \\
\hline 2005 & 100 & 4,29 & 1,59 & 0,98 & 0,97 & 1,99 & 4,12 & 86,06 \\
\hline
\end{tabular}

Таблица 3 - Долгосрочная тенденция роста государственных расходов в странах Организации экономического сотрудничества и развития (ОЭСР) в период 1870-2011 гг., \% ВВП [18, p. 3; 19]

\begin{tabular}{|c|c|c|c|c|c|c|c|c|}
\hline \multirow{2}{*}{ Страна } & \multicolumn{8}{|c|}{ Общие государственные расходы, \% ВВП } \\
\hline & 1870 г. & 1913 г. & 1920 г. & 1937 г. & 1960 г. & 1980 г. & 1990 г. & 2011 г. \\
\hline Австрия & - & - & 14,7 & 20,6 & 35,7 & 48,1 & 38,6 & 50,8 \\
\hline Бельгия & - & 13,8 & 22,1 & 21,8 & 30,3 & 57,8 & 54,3 & 53,5 \\
\hline Великобритания & 9,4 & 12,7 & 26,2 & 30,0 & 32,2 & 43,0 & 39,9 & 47,9 \\
\hline Германия & 10,0 & 14,2 & 25,0 & 34,1 & 32,4 & 47,9 & 45,1 & 45,0 \\
\hline Ирландия & - & - & 18,8 & 25,5 & 28,0 & 48,9 & 41,2 & \\
\hline Испания & - & 11,0 & 8,3 & 13,2 & 18,8 & 32,2 & 42,0 & 45,9 \\
\hline Италия & 11,9 & 11,1 & 22,5 & 24,5 & 30,1 & 42,1 & 53,4 & 49,9 \\
\hline Канада & - & - & 16,7 & 25,0 & 28,6 & 38,8 & 46,0 & 44,1 \\
\hline Нидерланды & 9,1 & 9,0 & 13,5 & 19,0 & 33,7 & 55,8 & 54,1 & 50,1 \\
\hline Норвегия & 5,9 & 9,3 & 16,0 & 11,8 & 29,9 & 43,8 & 54,9 & 43,9 \\
\hline США & 7,3 & 7,5 & 12,1 & 19,7 & 27,0 & 31,4 & 32,8 & 41,7 \\
\hline Франция & 12,6 & 17,0 & 27,6 & 29,0 & 34,6 & 46,1 & 49,8 & 55,9 \\
\hline Швеция & 5,7 & 10,4 & 10,9 & 16,5 & 31,0 & 60,1 & 59,1 & 51,5 \\
\hline Швейцария & 16,5 & 14,0 & 17,0 & 24,1 & 17,2 & 32,8 & 33,5 & 33,9 \\
\hline Япония & 8,8 & 8,3 & 14,8 & 25,4 & 17,5 & 32,0 & 31,3 & 42,3 \\
\hline $\begin{array}{l}\text { В среднем по странам } \\
\text { ОЭСР }\end{array}$ & 10,5 & 11,9 & 18,2 & 22,4 & 27,9 & 43,1 & 44,8 & 45,4 \\
\hline
\end{tabular}

В наши дни многие страны мира, прежде всего, флагманы мировой экономики - ЕС и США, вновь озаботились проблематикой «реиндустриализации» и «возрождения промышленности», возведя ее в ранг государственной стратегии. В частности, в 2012 г. принята к исполнению предусматривающая возвращение «домой» сотен американских корпораций Национальная стратегия возрождения обрабатывающей промышленности США, которые сегодня, также как и ЕС, попали в угрожающую зависимость от импорта из-за масштабного вывода своих промышленных предприятий в развивающиеся страны. Обнародованная в 2013 г. Стратегия возрождения промышленности Японии поставила перед страной задачу ее возврата на место лидера мирового научно-технического прогресса.

Заслуживает пристального изучения опыт целенаправленного индустриального развития нынешнего ЕС, который впервые вывел промышленную политику на наднациональный, межгосударственный уровень. Подлинным прорывом на концептуально-теоретическом уровне формирования новой индустриальной экономики следует считать тот факт, что страны ЕС с традиционного уровня борьбы за «здоровую конкуренцию» внутри союза постепенно поднялись до осознания необходимости формирования его коллективной конкурентоспособности на внешних рынках. Специалисты отмечают важную деталь - в последние годы наши западные соседи в качестве стратегического приоритета развития обозначают не просто промышленную политику, а достижение именно промышленной конкурентоспособности ЕС как целостной экономической системы. В частности, официально реализуемая с 2012 г. Стратегия промышленной политики Европейского союза предусматривает планомерное увеличение к 2020 году доли обрабатывающей промышленности в общем ВВП входящих в содружество стран на $30 \%$.

В дополнении к этому лидеры мировой экономики в современных условиях предпринимают беспрецедентные и очевидно нерыночные усилия для сохранения своего коллективного лидерства в области НТП и промышленного развития. Немногие знают, да это и не афишируется, что технологически развитые державы в 1996 г. заключили так называемые Вассенарские соглашения, строго запрещающие передачу современных, в том числе сугубо мирных технологий третьим странам. Вместо продажи результатов исследований и разработок лидеры мировой экономики организовали обмен ими между собой на основе своеобразного бартера, что сегодня даже обозначается специальным термином - хайтеграция [20, с. 117]. По мнению профессора С.С. Губанова, «на самом деле никакого рынка высоких тех- 
нологий в мире нет, как и рынка высокотехнологичной продукции. В отличие от России, открытой ныне компрадорами для иностранного капитала настежь, как в 1612 г. Кремль для поляков распахнула семибоярщина, в мире продается и покупается не все. Никто не продаст России ни одну высокую технологию - ни за злато, ни за серебро, ни тем более за пустые долларовые фантики. Свободной купли-продажи высокотехнологичных средств производства не существует - их оборот давно и жестко замкнут в контуре крупнейших ТНК, откуда не выходит» [1, с. 206].

Кстати говоря, это исчерпывающе объясняет, почему иностранные инвестиции и приватизация с их участием на всем постсоветском пространстве вопреки нашим наивным упованиям привели не к технико-технологическому прогрессу, а к банальному переходу собственности под контроль иностранных и ассоциированных с ними национальных инвесторов-компрадоров, заинтересованных преимущественно в «выкачивании» наших природных ресурсов на Запад. Оснащение же передовыми технологиями своих стратегических конкурентов, которые в составе СССР еще недавно на равных соперничали с самими США по ряду направлений НТП, в планы Запада, увы, явно не входит. Иными словами, традиционные надежды некоторых ученых на то, что нам удастся осуществить новую индустриализацию по принципу «Заграница нам поможет!» или же закупая современные технологии на мировом рынке, беспочвенны и вредны.

Таким образом, допущенная в процессе приватизации рыночная дезинтеграция экономики, изгнание из нее государства в надежде на то, что «невидимая рука» рынка сама собой все обустроит, упования на «здоровую конкуренцию» на фоне усиления монопольной силы западных ТНК и укрепления экономической роли национальных правительств, тщетные ожидания помощи от иностранных инвесторов - все это сделало экономики стран бывшего СССР неконкурентоспособными. Как следствие, за годы рыночных реформ многие сегменты внутреннего рынка ЕЭП, к сожалению, захвачены нашими стратегическими конкурентами. Из табл. 4 видно, что наибольшие потери наши страны несут на сегментах реализации продукции, относящейся к высшим (согласно классификации NACE Евросоюза) уровням технологичности, а также на отдельных, однако емких и потому весьма чувствительных рынках низкотехнологичных товаров.

Мы уверены, главная наша проблема в том, что большинство влиятельных отечественных экономистов почемуто считают, что капитализм однороден в пространстве и неизменен во времени. Однако объективный анализ его эволюции доказывает, что капитализм, как и все в этом мире, непрерывно изменяется, развивается, эволюционирует, переходя от одной стадии к другой. При этом, согласно точке зрения профессора С.С. Губанова, стержневое, магистральное направление этой эволюции - переход от предельно дезинтегрированной («атомарной») собственности сначала к горизонтально-, далее к вертикально- и, наконец, к системно-интегрированной ее формам (табл. 5). Следует отметить, что указанная трансформация собственности осуществляется в полном соответствии с описанным выше законом вертикальной интеграции.

На основании изложенного можно сделать следующий принципиальный вывод - для успешной модернизации и конкурентоспособного развития странам ЕАЭС, прежде всего, необходимо кардинально пересмотреть базовую доктрину развития. По примеру технологически развитых стран нам необходимо уже сегодня отказаться от безнадежно устаревшей (времен А. Смита) конкурентно-рыночной научно-образовательной парадигмы, ориентирующей наши страны на низший, зависимый, свойственный колониальным странам частнособственнический капитализм. Важно перенастроить отечественную научно-образовательную систему на интеграционную парадигму экономических знаний, нацеливающую на формирование высшего, господствующего капитализма государственно-корпоративного типа. 
Таблица 4 - Структура реализации промышленной продукции на внутреннем рынке ЕЭП в 2012 году

\begin{tabular}{|c|c|c|c|}
\hline Вид продукции & $\begin{array}{c}\text { Реализация на свои } \\
\text { национальные рынки, \% }\end{array}$ & $\begin{array}{c}\text { Взаимная } \\
\text { торговля, \% }\end{array}$ & $\begin{array}{l}\text { Импорт из тре- } \\
\text { тьих стран, \% }\end{array}$ \\
\hline \multicolumn{4}{|l|}{ Продукция высокой технологии } \\
\hline Фармацевтическая продукция & 28,2 & 1,5 & 70,3 \\
\hline $\begin{array}{l}\text { Электрооборудование, электронное и оптиче- } \\
\text { ское оборудование }\end{array}$ & 40,5 & 4,3 & 55,2 \\
\hline \multicolumn{4}{|l|}{ Продукция средневысокой технологии } \\
\hline Машины и оборудование & 44,6 & 4,3 & 51,0 \\
\hline Продукция химической промышленности & 45,0 & 4,8 & 50,2 \\
\hline Продукция машиностроения & 48,1 & 4,2 & 47,7 \\
\hline Транспортные средства и оборудование & 55,6 & 4,1 & 40,3 \\
\hline \multicolumn{4}{|l|}{ Продукция средненизкой технологии } \\
\hline Резиновые и пластмассовые изделия & 59,6 & 6,5 & 33,9 \\
\hline $\begin{array}{l}\text { Продукция обрабатывающей промышленно- } \\
\text { сти }\end{array}$ & 65,1 & 4,5 & 30,5 \\
\hline $\begin{array}{l}\text { Металлургическое производство и готовые } \\
\text { металлоизделия }\end{array}$ & 73,1 & 6,8 & 20,2 \\
\hline $\begin{array}{l}\text { Прочие неметаллические минеральные про- } \\
\text { дукты }\end{array}$ & 85,2 & 3,1 & 11,7 \\
\hline \multicolumn{4}{|l|}{ Продукция низкой технологии } \\
\hline Кожа, изделия из кожи и обувь & 22,1 & 4,1 & 73,8 \\
\hline Продукция легкой промышленности в целом & 32,1 & 6,0 & 61,9 \\
\hline Текстиль и швейные изделия & 35,6 & 6,6 & 57,8 \\
\hline $\begin{array}{l}\text { Продукция деревообработки и изделия из де- } \\
\text { рева, мебель }\end{array}$ & 46,9 & 10,7 & 42,4 \\
\hline Пищевые продукты, включая напитки и табак & 79,7 & 3,9 & 16,4 \\
\hline $\begin{array}{l}\text { Целлюлозно-бумажная продукция, издатель- } \\
\text { ская деятельность }\end{array}$ & 78,9 & 2,7 & 18,4 \\
\hline $\begin{array}{l}\text { Продукция горнодобывающей промышленно- } \\
\text { сти }\end{array}$ & 50,3 & 43,8 & 5,9 \\
\hline Промышленная продукция, всего & 68,6 & 5,4 & 26,1 \\
\hline
\end{tabular}

Источник: составлено на основе данных доклада С.С. Сидорского «О подходах к промышленной политике в рамках Единого экономического пространства» на Международном семинаре «Согласованная промышленная политика как инструмент евразийской интеграции» (26-27 сентября 2013 г., г. Москва). 
Таблица 5 - Стадии (уклады) капитализма и их характерные особенности

\begin{tabular}{|c|c|c|c|c|c|c|}
\hline $\begin{array}{c}\text { Стадии } \\
\text { капитализма, } \\
\text { от низшей } \\
\text { к высшей }\end{array}$ & $\begin{array}{c}\text { Преобладающая фор- } \\
\text { ма собственности }\end{array}$ & $\begin{array}{c}\text { Субъект } \\
\text { собственности }\end{array}$ & $\begin{array}{c}\text { Основное } \\
\text { звено } \\
\text { воспроизводства }\end{array}$ & $\begin{array}{l}\text { Целевая } \\
\text { функция }\end{array}$ & $\begin{array}{c}\text { Масштаб } \\
\text { планирования }\end{array}$ & $\begin{array}{c}\text { Характер } \\
\text { конкуренции }\end{array}$ \\
\hline $\begin{array}{l}\text { Частнокапиталистическая } \\
\text { (конец XVII-середина } \\
\text { XIX вв.) }\end{array}$ & $\begin{array}{l}\text { Дезинтегрированная, } \\
\text { атомарная }\end{array}$ & $\begin{array}{l}\text { Персонифициро- } \\
\text { ванный: частный } \\
\text { капиталист }\end{array}$ & $\begin{array}{l}\text { Отраслевое пред- } \\
\text { приятие }\end{array}$ & $\begin{array}{l}\text { Частная } \\
\text { прибыль }\end{array}$ & $\begin{array}{l}\text { Локальный, в рам- } \\
\text { ках предприятия }\end{array}$ & $\begin{array}{l}\text { Конкуренция мелких и средних } \\
\text { производителей внутри страны }\end{array}$ \\
\hline $\begin{array}{l}\text { Государственно- } \\
\text { монополистическая (конец } \\
\text { XIX-начало XX вв.) } \\
\end{array}$ & $\begin{array}{l}\text { Горизонтально- } \\
\text { интегрированная }\end{array}$ & $\begin{array}{l}\text { Персонифициро- } \\
\text { ванный: отрасле- } \\
\text { вой капиталист } \\
\end{array}$ & $\begin{array}{l}\text { Отраслевая монопо- } \\
\text { лия }\end{array}$ & $\begin{array}{l}\text { Монополь- } \\
\text { ная при- } \\
\text { быль } \\
\end{array}$ & Отраслевой & $\begin{array}{l}\text { Конкуренция крупных отрас- } \\
\text { левых монополистов внутри } \\
\text { страны }\end{array}$ \\
\hline $\begin{array}{l}\text { Государственно- } \\
\text { корпоративная (середина } \\
\text { XX-настоящее время) }\end{array}$ & $\begin{array}{l}\text { Вертикально- } \\
\text { интегрированная }\end{array}$ & $\begin{array}{l}\text { Смешанный: кор- } \\
\text { поративный капи- } \\
\text { талист }\end{array}$ & $\begin{array}{l}\text { ТНК (транснацио- } \\
\text { нальная корпорация) }\end{array}$ & $\begin{array}{l}\text { Добавлен- } \\
\text { ная стои- } \\
\text { мость }\end{array}$ & $\begin{array}{l}\text { Макроэкономиче- } \\
\text { ский, в рамках } \\
\text { национальной эко- } \\
\text { номики }\end{array}$ & $\begin{array}{l}\text { Конкуренция сверхкрупных } \\
\text { национальных ТНК при патро- } \\
\text { наже национальных правитель- } \\
\text { ств на мировых рынках }\end{array}$ \\
\hline $\begin{array}{l}\text { Госкапиталистическая (с } \\
\text { середины XXI в.) }\end{array}$ & $\begin{array}{l}\text { Системно- } \\
\text { интегрированная }\end{array}$ & $\begin{array}{l}\text { Деперсонифици- } \\
\text { рованный: сово- } \\
\text { купный капита- } \\
\text { лист }\end{array}$ & $\begin{array}{l}\text { ЕНК (единый } \\
\text { народно- } \\
\text { хозяйственный ком- } \\
\text { плекс) }\end{array}$ & $\begin{array}{l}\text { Совокупная } \\
\text { покупа- } \\
\text { тельная } \\
\text { способность }\end{array}$ & $\begin{array}{l}\text { Народно- } \\
\text { хозяйственный }\end{array}$ & $\begin{array}{l}\text { Конкуренция стран и их блоков } \\
\text { на глобальном уровне }\end{array}$ \\
\hline
\end{tabular}


Кроме того, исходя из необходимости достижения глобальной конкурентоспособности ЕАЭС, Армения, Беларусь, Казахстан, Кыргызстан и Россия уже сегодня должны приступить к формированию и реализации межгосударственной промышленной политики, определить приоритеты и целевые показатели процессов промышленной интеграции. Речь должна идти не о «здоровой конкуренции» внутри ЕАЭС, а о совместных, согласованных действиях по вытеснению наших общих стратегических конкурентов со своих внутренних рынков, а затем о противодействии им на внешних рынках. Для этого необходимо всемерно поощрять создание и рост крупных и сверхкрупных вертикальноинтегрированных транснациональных корпораций (ТНК) с участием белорусского, российского, казахского, армянского, киргизского капиталов. Особенностями этих ТНК должны стать отнюдь не конкуренция, а кооперация и взаимное дополнение национальных ресурсов и производств.

Кстати говоря, необходимые правовые основы для этого имеются, поскольку статья 32Договора о Таможенном союзе и Едином экономическом пространстве прямо предусматривает, что участвующие в нем страны «обязуются способствовать созданию эффективных взаимодополняющих производств с учетом взаимных экономических интересов государств». Однако мы убеждены, что изложенное в данной статье положение сегодня требует дальнейшего существенного развития. Дело в том, что в наши дни вертикальная интеграция активов (положим, в рамках тех же ТНК) осуществляется, в основном, путем «слияний и поглощений» в соответствии с западной системой мировоззренческих ценностей, основу которой составляют принципы «верховенства прав сильного» и «господства-подчинения». Думается, перенесение этих «интеграционных» принципов на взаимоотношения союзных государств не даст заметного позитивного результата, поскольку может ущемлять национальные интересы сторон, а значит, вызвать противодействие подобной интеграции со стороны правительств. Мы убеждены, гарантированное наднациональным законодательством соблюдение интересов сторон в процессе интеграции национальных компаний может ее существенно облегчить и ускорить. И действительно, даже относительно малое белорусское предприятие может безбоязненно войти в состав более крупной российской корпорации в том случае, если Беларусь будет иметь надежные гарантии того, что: а) ее предприятие не будет остановлено, перепрофилировано, сокращено и т.п., а наоборот, получит дальнейшее развитие; б) сохранятся социальные ориентиры его развития; в) положение трудового коллектива не ухудшится; г) совместно заработанная прибыль будет делиться между сторонами справедливо, то есть пропорционально вкладу в совместно произведенный продукт, а не по остаточному принципу, когда «львиную долю» забирает сильный и т.п.; д) налоговая база страны не уменьшится и т.п.

Образование интегрированных структур, по нашему мнению, значительно упростится и в том случае, если в фундамент их деятельности будет законодательно заложен принцип «соинвестирования», нивелирующий классический рыночный принцип «максимизации индивидуальной прибыли». Партнеры-соинвесторы, справедливо деля как прибыли, так и возможные убытки от реализации совместно выполняемого проекта, нацелены не на получение индивидуальной прибыли от выполнения своей отдельной части проекта, а на максимизацию общей прибыли от осуществления проекта в целом. Разумеется, это достижимо лишь при условии, что совместно заработанная прибыль более или менее справедливо распределяется между всеми участниками проекта, а не преимущественно среди тех, кто контролирует его стадии, связанные с получением доходов от него и, соответственно, возникновением прибыли. Только в этом случае можно надеяться на то, что те же инжиниринговые, научно-технические, инновационные, технологические центры или участники консорциумов будут заинтересованы не просто в оказании партнерам предельно дорогих платных услуг, а в максимальной эффективности реализуемого проекта в целом. И это кардинально отличает их от тех же партнеров-кооператоров, максимизирующих индивидуальный результат, в том числе за счет «выкачивания» прибыли из партнеров и снижения эффективности проекта в целом.

Жизненно важно продолжить укрепление плановых начал развития экономических систем всех уровней. Если еще недавно в России было табуировано даже употребление терминов «план» и «планирование», то сегодня там разработан и вступил в силу Федеральный Закон Российской Федерации «О стратегическом планировании в Российской Федерации» от 28 июля 2014 г. №172-Ф3, четко определивший его цели, задачи, методы и инструменты. Это означает, что высшее российское руководство страны постепенно приходит к осознанию неизбежности усилий, нацеленных на планомерное, ускоренное индустриальное развитие. Другой наш партнер по ЕАЭС - Казахстан недавно также известил о новой экономической политике, в том числе о реализации Государственной программы форсированного инновационного индустриального развития на 2015-2019 годы (ГПФИИР 2015-2019) как стратегического плана ускоренного развития промышленного комплекса страны.

Что касается Беларуси, то признаваемые сегодня даже ее недругами успехи, кстати, достигнутые в условиях острого дефицита собственных природных ресурсов, обусловлены исключительно планомерным развитием ее экономики, включая отечественный промышленный комплекс. Одним из стратегических документов в этой области является Программа развития промышленного комплекса Республики Беларусь на период до 2020 года, утвержденная Постановлением Совета Министров Республики Беларусь от 05.07.2012 г. № 622. Она направлена на формирование конкурентоспособного инновационного промышленного комплекса, ориентированного на создание высокопроизводительных рабочих мест и рост производительности труда по добавленной стоимости не менее 50 \% от европейского уровня, увеличения выпуска соответствующей мировым стандартам продукции и наращивания экспортного потенциала конкурентоспособности. В Программе констатируется, что промышленный комплекс является основой развития национальной экономики, обеспечения экономической безопасности страны. Он формирует около 30\% создаваемого в республике ВВП, более 90\% объема экспорта и основную сумму валютных поступлений в республику, обеспечивает рабочими местами четверть экономически активного населения страны. 
Изложенное означает следующее - страны ЕАЭС уже вплотную подошли к тому, чтобы плановые методы хозяйствования были «подняты» с национального на межгосударственный уровень и сделались основой деятельности Евразийской экономической комиссии.

Таким образом, сегодня усилия ведущих ученых-экономистов необходимо сосредоточить на разработке экономической научно-образовательной парадигмы, всецело ориентированной на национальные интересы. Вместо нынешнего англо-саксонского неоклассического «мейнстрима», лукаво нацеливающего нас на стихийно-рыночную дезинтеграцию и «войну всех со всеми», необходимо перейти к такой системе экономических знаний, которая позволит странам ЕАЭС и их предприятиям наиболее полно и планомерно реализовать системный, синергетический эффект от интеграции - кооперации и сотрудничества, объединения капиталов и ресурсов.

\section{ВЫВОДЫ}

Сегодня, принимая во внимание описанные выше общемировые тенденции к интеграции капиталов и производств, страны ЕАЭС выходят на новый, принципиально более высокий мировоззренческий уровень взаимодействия, объективно подразумевающий отказ от внутренней конкуренции в пользу объединения усилий и интеграции, кооперации и сотрудничества во имя достижения глобальной конкурентоспособности на внешних границах. На наш взгляд, пришла пора осознать, что уже давно назрела смена доктрины развития - отказ от лукаво навязанной нам Западом безнадежно устаревшей конкурентно-рыночной парадигмы в пользу интеграционной, кооперационной системы экономических знаний, нацеленной на целенаправленную, планомерную реализацию системного, кооперационного, синергетического эффекта в рамках современной экономики государственно-корпоративного типа (табл. 5).

Учитывая жизненную значимость интеграционных процессов в рамках ЕАЭС и необходимость их существенного ускорения, мы считаем, что реализация этой задачи существенно облегчится, если в фундамент нашей интеграции будут положены новые принципы взаимодействия, соответствующие системе коллективистских мировоззренческих ценностей нашей восточнославянской цивилизации. Сегодня актуален решительный отказ от разрушительной внутренней конкуренции наших предприятий друг с другом в пользу целенаправленной кооперации, планомерного сотрудничества и объединения дефицитных ресурсов во имя достижения глобальной, коллективной конкурентоспособности стран ЕАЭС. В связи с этим создание и всемерное развитие белорусско-российских, белорусскоказахстанских, российско-казахстанских и т.д. вертикально-интегрированных ТНК должно стать главным стратегическим приоритетом развития нашего нового союза, фундаментом его промышленной политики.

Перечисленные меры в наибольшей мере позволят удовлетворить требованиям закона вертикальной интеграции, придадут новый импульс к образованию межгосударственных вертикально интегрированных структур и новой индустриализации национальных экономик стран ЕАЭС, включая модернизацию промышленного комплекса - фундамента экономической и военно-политической независимости любой современной державы. Только в этом случае в преддверии суровых испытаний, которые сулит миру столь бурно начавшийся XXI век, наш новый союз сможет более или менее на равных конкурировать с США, Китаем, Японией, ЕС и их ТНК, а значит, наши страны получат шанс на сохранение своего экономического и политического суверенитета.

\section{ЛИТЕРАТУРА}

1. Губанов, С.С. Державный прорыв. Неоиндустриализация России и вертикальная интеграция / С.С. Губанов. М.: Книжный мир, 2012. -224 с.

2. Губанов, С.С. Иллюзии постиндустриализма / С.С. Губанов // Беларуская думка. - 2009. - №6. - С. 77-83.

3. Логачев, В. Целевое содержание предстоящей неоиндустриализации: «пост» или «нео»? / В. Логачев, Д. Кочергин // Экономист. - 2013. - №4. - С. 11-19.

4. Матвиенко, В. О новой индустриализации России / В. Матвиенко // Экономист. - 2013. - №7. - С. 3-5.

5. Губанов, С. Неоиндустриализация плюс вертикальная интеграция (о формуле развития России) / С. Губанов // Экономист. - 2008. - №9. - С. 3-27.

6. Россия - Беларусь: инновационная политика и интеграционное взаимодействие: колл. монография / Под ред. Г.А. Власкина. - М.: Институт экономики РАН, 2006. - 268 с.

7. Власкин, Г.А. Промышленная политика в условиях перехода к инновационной экономике: опыт стран Центральной и Восточной Европы и СНГ: монография / Г.А. Власкин, Е.Б. Ленчук; Ин-т междунар. экон. и полит. исслед. РАН. - М.: Наука, 2006. - 246 с.

8. Белорусский путь / Под ред. О.В. Пролесковского и Л.Е. Криштаповича; Министерство информации Республики Беларусь. - Минск: Мастацкая літаратура, 2012. - 510 с.

9. Государственное регулирование переходной экономики: колл. монография / под общ. ред. С.А. Пелиха; Академия управления при Президенте Республики Беларусь. - Минск: Право и экономика, 2008. - 490 с.

10. Пелих, С.А. Организация производства в условиях переходной экономики / С.А. Пелих [и др.]; под общ. ред. С.А. Пелиха. - Академия управл. при Президенте Респ. Беларусь. - Минск: Право и экономика, $2007 .-508$ с.

11. Винник, В.Т. Источники национально-экономического развития: ловушки либерализма / В.Т. Винник. Минск: УП «Технопринт», 2005. - 149 с.

12. Байнев, В. Ф. Переход к инновационной экономике в условиях межгосударственной интеграции: тенденции, проблемы, белорусский опыт: монография / В.Ф. Байнев, В.В. Саевич; под общ. ред. проф. В.Ф. Байнева. - Минск: Право и экономика, 2007. - 180 с. 
13. Байнев, В.Ф. Научно-технический прогресс и устойчивое развитие: теория и практика полезностной (потребительно-стоимостной) оценки эффективности новой техники: монография / В.Ф. Байнев, Е.А. Дадеркина; под общ. ред. В.Ф. Байнева; Белорусский государственный университет. - Минск: Право и экономика, 2008. - 189 с.

14. Байнев, В.Ф. Социально-экономическое развитие и «ловушки» рыночного либерализма: курс на неоиндустриализацию: монография / В.Ф. Байнев, В.Т. Винник; под общ. и науч. ред. В.Ф. Байнева. - Минск: Право и экономика, 2009. - $114 \mathrm{c.}$

15. Байнев, В.Ф. Монетарные факторы деиндустриализации / В.Ф. Байнев // Экономист. - Москва, 2009. - №4. - C. 35-46.

16. Сравнительный анализ: 2013/1990 // Официальный сайт «Экономической и философской газеты» [Электронный ресурс]. - Режим доступа: http://eifgaz.ru/2013-1990.htm - Дата доступа: 18.11.2014.

17. Гордеев, В.А. Тенденция к взаимодействию и сотрудничеству вместо конкуренции: новое подтверждение идеи Т.С. Хачатурова / В.А. Гордеев // Вестник Московского университета. - Серия 6 «Экономика». - 2007. - №2. C. $16-27$.

18. Tanzi, Vito. The Demise of the Nation State? / Vito Tanzi // IMF Working Paper 98/120. - 1998. - August. - P. 3-7. 19. OECD. Government at a Glance 2013 // OECD Publishing. - 2013. [Electronic resource] - Mode of access: http://www.oecd-ilibrary.org/docserver/download/4213201e.pdf. - Date of access: 20.12.2014.

20. Быков, А.А. Антикризисная стратегия предприятия: теория и методология исследования: Монография / А.А. Быков; Под общ. ред. проф. В.Н Шимова. - Минск: БГЭУ, 2005. - 167 с.

Статья поступила в редакиию 5 июня 2015 года. 